\title{
Space station design falls hostage to US-Russia missile deal...
}

Washington. The design of the space station being planned by the National Aeronautics and Space Administration (NASA) seems likely to be shaped more by what the United States feels it must offer the Russians in return for their signature on the Missile Technology Control Regime - an agreement to stop the spread of weapons technology - than by engineering or scientific considerations.

A final design for the proposed 'international space station' being negotiated between the United States and Russia will not now be ready until 22 December, NASA administrator Dan Goldin told a congressional hearing last week. And according to congressional aides, it will not be finalized until Vice President Al Gore visits Moscow after the Russian elections in November.

Goldin was speaking after his return from a visit to the Russian capital that coincided with the bloody showdown on Moscow's streets. He said that he had been strongly impressed by the commitment of the Russian team which had negotiated with him on the details of the recent US-Russia space cooperation agreement (see Nature 365, 101; 1993) against a backdrop of gunfire.

But he told a House of Representatives space subcommittee hearing that he had not yet discussed the space station, the third phase of the three-part deal, with the Russians. "Right now we've only talked about phases one and two", he said.

The space station is due to be discussed at another set of meetings this week, Goldin said. Under Gore's plan, the latest design for the space station will be presented to the White House by NASA on 1 November.

The first two phases of the US-Russian space deal are bilateral agreements. But the third phase is meant to involve the United States' existing space station partners namely Japan, Europe and Canada - as well. NASA officials were in Paris last week briefing the European Space Agency on their progress with the Russians.

At an earlier hearing of the space subcommittee, John Gibbons, President Clinton's science adviser, was pressed on why he had no details of the plan. In reply, Gibbons said he did not expect to see an agreement as such on 1 November. "I expect to see a set of options", he said.

Goldin appeared to admit his frustration at the way the decision on the final space station design is being drawn out. "I do not have full control of this process", he said. "I will just deliver the data."

The lack of information on the agreement with the Russians has angered congressmen who fought to save the space station from budget cuts this summer eventually prevailing in the House by 216 votes to 215 - only to find it once again bogged down in yet another redesign.

Goldin says NASA is now working on two programmes. One is the space station Alpha as accepted by Clinton in the summer, the other is the 'international' station involving the Russians. Boeing has already been named as prime contractor; but it will not now be told what it has to build until next March.

In testimony from the Congressional Research Service, space specialist Marcia Smith described the Gore plan as "fundamentally a foreign policy decision, not a choice based on space policy". Smith said that merging the space station with foreign policy objectives was likely to "complicate, rather than complete" the programme.

Meanwhile, the technical problems resulting from the US-Russian deal continue to mount. For example, in order to reach a station repositioned to suit the Russians, shuttle launches from Florida would have to fit in a five minute 'window' each day.

Goldin and Gibbons do not consider this a problem. But James Sensenbrenner (Republican, Wisconsin) says that only 30 out

\section{... as Europe plans solo comet trip}

London. The European Space Agency (ESA) is expected to give its formal approval next month to plans for the launch in 2003 of the first spacecraft to land scientific instruments on the surface of a comet. US scientists are being invited to participate; but the project will not, as originally intended, be run jointly with the US National Aeronautics and Space Administration (NASA).

The so-called Rosetta mission - named after the complex hieroglyphs found on the Rosetta stone in Egypt - will send a spacecraft to fly alongside a comet, most likely Schwassam-Wachmann 3, as it passes through the Solar System and eventually swings around the Sun. It will form the third of four 'cornerstone' missions that have been planned as the basis of ESA's space science programme since these were agreed in the mid-1980s.

Original plans for the mission were drawn up jointly between scientists at ESA and NASA, with the costs of up to $\$ 2$ billion to be split on a 40:60 basis. Funding from the two agencies was to have supported a more ambitious mission, including a vehicle that would have returned samples of the comet's surface to Earth for analysis.

Last year, however, following indica- of 86 shuttle launch attempts so far would have coped with such a restriction.

More importantly, the death of the Advanced Solid Rocket Motor in Congress two weeks ago leaves the United States with a lower shuttle launch capacity than its earlier plans had assumed.

The biggest question mark hangs over the wisdom of allowing the fate of an international programme that has already been almost destroyed by the vagaries of the US Congress to depend on the even greater vagaries of Russian politics.

In reply to a question from Tim Roemer (Democrat, Indiana) on what would happen if the Russians breach the missile treaty at some future date, Goldin said: "We'll have a back up as part of our planning process." Congress is unconvinced: in the words of one aide, such a "twin track" policy is " absolutely not possible".

If this is the case, then the Clinton administration may have to wait for political stability in Russia before it can proceed with the space station. But station supporters in Congress are asking whether such stability is likely to be assured by the time they next have to justify funding for the project in nine months time.

Colin Macilwain

\section{IMAGE UNAVAILABLE FOR COPYRIGHT REASONS}

\section{Rosetta: a 'cornerstone' mission (artist's impression).}

tions from NASA that the US contribution was unlikely to materialize, ESA agreed that the sample-return element was not essential to the mission's success, and that many of its scientific goals could be achieved by a more modest mission.

It was also accepted by ESA that European development work on solar arrays meant that it would no longer be necessary to rely on US technology to power the space 